\title{
The Association between Maternal Knowledge, Family Support, and Exclusive Breastfeeding in Siborong Borong Community Health Center, North Tapanuli, North Sumatera
}

\author{
Selferida Sipahutar'1), Namora Lumongga Lubis²), \\ Fazidah Agusliana Siregar ${ }^{2)}$ \\ ${ }^{1)}$ Masters Program in Public Health, Faculty of Public Health, \\ Universitas Sumatera Utara \\ 2)Faculty of Public Health, Universitas Sumatera Utara
}

\begin{abstract}
Background: Exclusive breastfeeding means that the infant receives only breast milk. No other liquids or solids are given - not even water - with the exception of oral rehydration solution, or drops/syrups of vitamins, minerals or medicines.WHO reported that nearly $90 \%$ of the under-five deaths occurred in developing countries and more than $40 \%$ of the deaths were due to diarrhea and acute respiratory infections. These diseases can be prevented by exclusive breastfeeding. This study aimed to examine the association between maternal knowledge, family support and exclusive breastfeeding in SiborongBorong Community Health Center, North Tapanuli, North Sumatera.

Subjects and Method: This was an analytic observational study with a cross-sectional design. The study was conducted at Siborongborong community health center, North Tapanuli, North Sumatera. A sample of 97 mothers who had children aged 6-12 months were selected for this study by proportional random sampling. The dependent variable was exclusive breastfeeding. The independent variables were maternal knowledge and family support. The data were analyzed by simple logistic regression.
\end{abstract}

Results: Exclusive breastfeeding was associated with maternal knowledge $(\mathrm{OR}=11.40 ; \mathrm{p}=0.001)$ and family support $(\mathrm{OR}=9.30 ; \mathrm{p}=0.001)$.

Conclusion: Exclusive breastfeeding is associated with maternal knowledge and family support.

Keywords: exclusive breastfeeding, maternal education, family support

\section{Correspondence:}

Selferida Sipahutar. Masters Program in Public Health, Faculty of Public Health, Universitas Sumatera Utara, Jl. Universitas 21, Medan 20115, North Sumatera, Indonesia. Email: selferidabidan@gmail.com. Mobile: +o81362123930

\section{BACKGROUND}

Exclusive breast milk (ASI) based on Government Regulation No. 33 of 2012 is breast milk given to babies from birth for six months, without adding or replacing other foods or drinks (except drugs, vitamins and minerals). Breast milk contains colostrum which is rich in antibodies because it contains high amounts of protein for endurance and germ so that exclusive breastfeeding can reduce the risk of death in infants (Indonesian Ministry of Health, 2015).
Maternal, infant and toddler mortality rates in Indonesia are still quite high. MDGs (Millennium Deployment Goals) Development Goals 2000-2015 and now continued with the 2015-2030 Sustainable Development Goals (SDGs) committed to reducing Maternal Mortality Rate (MMR) and Infant Mortality Rate (IMR). The SDGs have 17 goals and 169 targets, the first, second and third goals are related to health.

Nationally, the coverage of exclusive breastfeeding for 0-6 months in Indonesia fluctuated in the last six years, according to 
Susenas data Exclusive breastfeeding coverage of $34.3 \%$ in 2009,2010 showed that only $33.6 \%$ of infants received ASI, in 2011 that figure up to $42 \%$ and according to the 2012 IDHS, exclusive ASI coverage was 27\%. The coverage of exclusive breastfeeding for infants aged o- 6 months in the province of North Sumatra in 2016 was 33\% (Ministry of Health of Republic of Indonesia, 2016).

The coverage of Exclusive ASI in North Tapanuli in 2016 was $31.41 \%$. Of the highest number of health centers, the highest number of exclusive breastfed babies was Garoga Public Health Center, of which 94 0-6 months infants were given exclusive breastfeeding as many as 73 people (77.66\%) and the lowest in the Siborongborong Community Center of 447 breastfed infants Exclusive as many as 74 babies (16.67\%) and not given exclusive breastfeeding as many as 373 people (84.43\%) (Profil Taput, 2016).

Hafni et al., (2013) explained that knowledge and parity contributed to exclusive breastfeeding. The results of Rohani's study (2007) show that knowledge factors have an influence on exclusive breastfeeding, this indicates that there will be an increase in exclusive breastfeeding if accompanied by an increase in maternal knowledge about exclusive breastfeeding.

Subur, et al. (2012) have a significant relationship between education and knowledge of mothers. The lower the education, the lower a person's basic ability to think for decision-making, especially in giving exclusive breastfeeding to infants aged o-6 months. Family support and the role of health workers provide good information.

The low rate of breastfeeding is a threat to child development. Infants who are not breastfed at least until the age of 6 months, are more prone to experiencing nutritional deficiencies. Based on the 2010 basic health research data, the provision of breastfeeding in Indonesia is still a concern. The percentage of exclusively breastfed infants up to 6 months is only $15.3 \%$. This is due to public awareness in encouraging increased breastfeeding is still relatively low and lack of knowledge and lack of family support in exclusive breastfeeding (Maryunani, 2012). The author conducted an initial survey by taking data from the Siborong Borong Health Center with the number of babies aged 6 months as many as 363 babies, and those who received Exclusive ASI as many as 111 babies. The researcher obtained data in the form of health reports of infants and toddlers obtained there were 5 babies who experienced malnutrition, malnutrition 7 people, BGM as many as 4 people and aged o-6 months were fed for about 252 babies.

\section{SUBJECTS AND METHOD \\ 1. Study Design \\ This was a cross sectional study conducted at Siborongborong community health center, North Tapanuli, North Sumatera, Indonesia.}

\section{Population and Sample}

The population in the study was all mothers who had infants aged 6-12 months. A sample of 97 was selected by simple random sampling.

\section{Data analysis}

The data were analyzed to determine the relationship between knowledge, family support, and exclusive breastfeeding.

Bivariate analysis is used to express the analysis of two variables. Bivariate analysis was done by a multiple logistic regression.

\begin{tabular}{lc}
\hline \multicolumn{3}{c}{ RESULTS } \\
\hline The results of bivariate analysis of \\
knowledge variables with exclusive
\end{tabular}


breastfeeding showed that of the 48 mothers who have lack of knowledge, there were 44 respondents (91.7\%) who did not provide exclusive breastfeeding and 4 mothers (8.3\%) who gave exclusive breast- feeding and 49 mothers who were wellinformed, there were 24 mothers (49.0\%) who did not give exclusive breastfeeding and 25 mothers (51.0\%) who gave exclusive breastfeeding.

Table 1. Frequency distribution of maternal knowledge

\begin{tabular}{|c|c|c|c|c|}
\hline \multirow{2}{*}{ Knowledge } & \multirow{2}{*}{\multicolumn{2}{|c|}{ Exclusive Breastfeeding }} & \multirow[b]{2}{*}{ OR } & \multirow[b]{2}{*}{$\mathbf{p}$} \\
\hline & & & & \\
\hline $\begin{array}{l}\text { Low } \\
\text { High }\end{array}$ & $\begin{array}{l}4 \\
25\end{array}$ & 44 & 11.4 & 0.001 \\
\hline
\end{tabular}

Table 2. Frequency Distribution of Family Support and exclusive breastfeeding

\begin{tabular}{|c|c|c|c|c|}
\hline \multirow{2}{*}{ Family Support } & \multicolumn{2}{|c|}{ Exclusive Breastfeeding } & \multirow{2}{*}{ OR } & \multirow[b]{2}{*}{$\mathbf{p}$} \\
\hline & Yes & No & & \\
\hline $\begin{array}{l}\text { Weak } \\
\text { Strong }\end{array}$ & $\begin{array}{c}5 \\
24\end{array}$ & $\begin{array}{l}45 \\
23\end{array}$ & 9.3 & 0.001 \\
\hline
\end{tabular}

Mothers with higher knowledge increased exclusive breastfeeding (OR= $11.4 ; \mathrm{p}=0.001)$. Strong family support increased exclusive breastfeeding $(\mathrm{OR}=9.3$; $\mathrm{p}=0.001$ ).

\section{DISCUSSIONS}

\section{The association of knowledge and exclusive breastfeeding}

Knowledge was associated with exclusive breastfeeding. Mothers with higher knowledge increased exclusive breastfeeding.

The result of this study was in line with Rohani (2007), which stated that knowledge has an influence on exclusive breastfeeding. It indicated that an increase of exclusive breastfeeding supported by maternal knowledge about exclusive breastfeeding. Knowledge was the result of knowing, and this happened after someone has sensed a certain object. Sensing occurred through the human senses, namely vision, hearing, smell, feeling, and touch. Knowledge (cognitive) was a very important domain in shaping someone's actions.

Incorrect information about the importance of breastfeeding made mothers unsuccessful in giving exclusive breastfeeding to their babies. A group that cared about breast milk consistently continued to say the importance of early breastfeeding in a baby's life. They believe that the low success of exclusive breastfeeding was due to a lack of maternal knowledge.

\section{The association of family support and exclusive breastfeeding}

Family support was associated with exclusive breastfeeding. Strong family support increased exclusive breastfeeding.

Subjective support affects exclusive breastfeeding process was the willingness of the husband to share housework when the mother needed breastfeeding or rest, husband's concern for the nutritional intake of breastfeeding mothers, the husband's willingness to be a place of sharing and complaining during the breastfeeding process, and the husband's willingness to accompany when the mother has to breastfeed at night.

Family support can be in the form of information support such as providing information on exclusive breastfeeding, providing motivation to the mother and convincing the mother that the mother was able to provide Exclusive Breastfeeding to her baby, providing adequate nutrition to the mother during breastfeeding and the 
most important thing was that the family was involved in housework that can be done so that breastfeeding mothers were more focused on taking care of their babies without being burdened with the usual housework.$$
\text { REFERENCES }
$$

$\overline{\text { Almatsier, Sunita et al. (2011). Gizi Seim- }}$ bang dalam Daur Kehidupan, Jakarta: Gramedia Pustaka Utama.

Afifah D (2009). Faktor yang berperan dalam kegagalan praktik pemberian asi eksklusif. Magister Gizi Pasca Sarjana Universitas Diponegoro

Hikmawati, Mateus S, Asri (2008). Risk factors of failure to give breastfeeding during two months (Case study of infants aged 3 to 6 months old in Banyumas District).

Isroni, Astuti (2010). Determinan Pemberian ASI Eksklusif pada Ibu Menyusui, Jakarta.
}

Kemenkes RI (2012). Peraturan Pemeritah RI No.33 Tentang Pemberian Air Susu Ibu Eksklusif, Jakarta

Maryunani (2012). Insiasi Menyusui Dini, ASI Eksklusif \& Manajemen Laktasi, Jakarta: Trans Info Media.

Rahmawati et al. (2010). Faktor-faktor yang mempengaruhi pemberian ASI eksklusif pada ibu menyusui di kelurahan Pedalangan kecamatan Banyumanik kota Semarang. Jurnal Kesehatan. 1(1): 8-17.

(2013). Hubungan antara karakteristik ibu, peran petugas kesehatan, dan dukungan keluarga dengan pemberian ASI eksklusif di wilayah kerja puskesmas Ponto Cani Kabupaten Bone.

Subur, Widiyanto et al. (2012). Hubungan Pendidikan dan Pengetahuan Ibu tentang ASI Eksklusif dengan Sikap Terhadap Pemberian ASI Eksklusif 